\title{
Does organisational commitment enhance the relationship between job involvement and in-role performance?
}

\author{
Authors: \\ Talat Islam ${ }^{1}$ \\ Saif Ur Rehman Khan ${ }^{1}$ \\ Ungku N.U. Ahmad ${ }^{1}$ \\ Ishfaq Ahmed ${ }^{1}$

\section{Affiliations:} \\ ${ }^{1}$ Faculty of management \\ and Human Resource \\ Development, Universiti \\ Teknologi Malaysia, Johor \\ Campus, Malaysia \\ Correspondence to: \\ Talat Islam \\ Email: \\ talatislam@yahoo.com \\ Postal address: \\ E-2-04, Jalan Pulai Perdana, \\ 2/7 Taman Sri Pulai Perdana, \\ Skudai, Johor Bahru 81110 , \\ Malaysia \\ Dates: \\ Received: 24 Jan. 2012 \\ Accepted: 26 Sept. 2012 \\ Published: 30 Nov. 2012 \\ How to cite this article: \\ Islam, T., Khan, S.U.R., \\ Ahmad, U.N.U., \& Ahmed, I. \\ (2012). Does organisational \\ commitment enhance \\ the relationship between \\ job involvement and in- \\ role performance? SA \\ Journal of Human Resource \\ Management/SA Tydskrif vir \\ Menslikehulpbronbestuur, \\ 10(2), Art. \#460, 9 pages. \\ http://dx.doi.org/10.4102/ \\ sajhrm.v10i2.460
}

C 2012. The Authors. Licensee: AOSIS OpenJournals. This work is licensed under the Creative Commons Attribution License.
Orientation: Job involvement is essential for the performance of employees. Prior researchers have found a weak relationship between job involvement and job performance, but dimensions of commitment have been considered as a mediator to enhance the relationship.

Research purpose: This research is aimed at discovering the role of organisational commitment as a mediating variable between the relationship of job involvement and performance.

Motivation for the study: The aim of organisations today is to outperform each other in every respect. In order to realise this, the role of employees is crucial. To elicit the best from employees requires much attention from organisations. This research is focused on this specific issue, namely, increasing employees' performance.

Research design, approach and method: The researchers have used structured questionnaires using the quantitative approach. A similar research methodology using the survey method was applied by the researchers to make the results comparable. The simple random sampling technique was used. Data was evaluated on the basis of 208 completed questionnaires.

Main findings: Findings of the study indicate that there is a relationship between job involvement and in-role performance. Affective and normative commitment can act as mediator. However, continuance commitment is not a mediator in this relationship.

Practical/managerial implications: It is important for organisations that want to gain a competitive edge over its rivals to enhance the level of involvement of its employees.

Contribution/value-add: The results of this study will provide a new dimension for managers on how to gain a competitive advantage over rival firms with regard to performance by increasing the level of job involvement.

\section{Introduction}

Job involvement has received substantial attention because of its role in generating positive organisational outcomes, for example, employee commitment (Ahmed \& Islam, 2011; Ketchand \& Strawser, 2001; Mathieu \& Zajac, 1990; Meyer, Paunonen, Gellatly, Goffin \& Jakson, 1989), employee motivation (Hackman \& Lawler, 1971), job satisfaction (Gerpott, 1990; Mathieu \& Farr, 1991; Paterson \& O’Driscoll, 1990; Shore et al., 1990), in-role performance (Brown, 1996; Brown \& Leigh, 1996; Cron, 1984; Dubinsky \& Hartley, 1986; Mohsan et al., 2011) and organisational citizenship behaviour (Diefendorff, Brown, Kamin \& Lord, 2002; Mohsan et al., 2011).

Kanungo (1982) has defined job involvement as a psychological identification or commitment with the job. Furthermore, Paullay, Alliger and Stone-Romero (1994) added to this definition by stating that it is the degree to which one is cognitively anxious about, engaged with and concerned about ones present job. Those individuals who are more involved in their job consider their work to be a vital part of their lives and their feelings are closely connected with their performance at work (Lodahl \& Kejner, 1965). Thus, employees with high job involvement have greater work focus and make it an essential part of their personal life (Hackett, Lapierre \& Hausdorf, 2001).

Job involvement, to some extent, is similar to organisational commitment because both constructs are concerned with the employee's recognition at work. However the difference between both constructs is that job involvement is concerned with the current or latest job of the employee (Brown, 1996), whilst organisational commitment is the willingness of an employee to be a part of the organisation in the future (Uygur, 2004). Thus, it is possible for an employee to be highly involved in his or her job, but not to be committed to the organisation (Blau \& Boal, 1987). 
Job involvement is the outcome of two factors, namely, personal and organisational factors (Sekeran, 1989; Sekeran \& Mowday, 1981). Personal characteristics such as age, gender, work experience and education are closely associated with job involvement (Rabinowitz \& Hall, 1977). Organisational factors, such as the characteristics of the job, also positively influence job involvement (Brown, 1996).

Existing literature on the association between job involvement and in-role performance demonstrates a weak association of constructs, which requires an in-depth investigation. As Brown and Leigh (1996) suggest, this weak relationship may be caused by the presence of other constructs. Taking this into consideration, this study is an attempt to explore the relationship between job involvement, commitment and inrole performance.

\section{Objectives of the study}

The objectives of the study are:

- to determine the relationship between job involvement and in-role job performance

- to determine the mediating role of organisational commitment between job involvement and in-role job performance

- to determine the mediating effect of affective, continuance and normative commitment between the relationship of job involvement and in-role job performance.

\section{Literature review}

\section{Job involvement and in-role job performance}

According to Borman and Motowidlo (1997), in-role job performance relates to the activities an employee's formal role requires. Researchers have found that job involvement has a positive impact on the employee's motivation and efforts (Hackman \& Lawler, 1971), which leads to a high level of in-role job performance (Brown, 1996). Earlier studies supported this relationship (i.e. Diefendorff et al., 2002; Mohsan et al., 2011; Rotenberry \& Moberg, 2007). For instance, Brown and Leigh (1996) found a positive and weak relationship between job involvement and in-role job performance, whilst the relationship with the mediation role of efforts was non-significant.

The literature has shown that few researchers try to explore the relationship between job involvement and in-role job performance. Results provided by the researchers clearly indicate a weak but significant relationship between job involvement and in-role job performance. For example, Diefendorff et al. (2002) found a small relationship (i.e. $r=.19, p<.05)$, Rotenberry and Moberg (2007) found a weak but significant relationship (i.e. $r=.15, p<.05$ ), whilst the study conducted by Mohsan et al. (2011) also found a weak but significant relationship (i.e. $r=.32, p<.03$ ):

- Hypothesis 1: There is positive and significant relationship between job involvement and in- role job performance.

\section{Affective commitment}

In the literature, organisational commitment is widely considered an affective or emotional attachment to the organisation, such that the strongly committed individual is involved and enjoys membership of the organisation (Allen \& Meyer, 1990). Employees who have high levels of organisational identification have enhanced feelings of belonging to their organisation and are more psychologically attached to it (Lee \& Peccei, 2007). Thus, employees with strong affective commitment remain with the organisation because they want to do so (Allen \& Meyer, 1996). Affective commitment tends to correlate more strongly with any given outcome variable, including the focal behaviour (Meyer \& Herscovitch, 2001). Organisational-based psychological ownership is concerned with the individual member's feelings of possession and psychological connection to the organisation as a whole, including organisational culture and climate, attitudes of senior management, corporate goals and vision, reputation of the organisation, and corporate policies and procedures (Mayhew, Ashkanasy \& Dan Gardner, 2007). Thus, developing affective commitment should focus on work experiences and job characteristics such as autonomy, task significance, task identity, skill variety, supervisory feedback and organisational dependability, all of which have been identified as significant antecedents of affective commitment (Jaros, 1997). Porter, Steers, Mowday and Boulian (1974, p. 606) further characterises affective commitment according to the following three factors:

(1) belief in and acceptance of the organization's goals and values, (2) a willingness to focus effort on helping the organization achieve its goals, and (3) a desire to maintain organizational membership. (p. 606)

\section{The mediating role of organisational commitment}

Today's organisations have to compete globally with their competitors and each organisation attempts to gain a greater advantage over its rivals. To attain this advantage organisations are trying to win the trust of their key employees along with their commitment level (Rotenberry \& Moberg, 2007). As argued by Feldman and Moore (1982), more committed employees try their best to uplift the organisation they work for and this provides these organisations with a competitive edge over their rivals.

Organisational commitment can be defined as the willingness of the employee to belong to the organisation, participate in the work of the organisation and identify with the organisation (Allen \& Meyer, 1990). This definition of organisational commitment involves three basic elements, namely (1) acceptance of all the goals of the organisation, (2) willingness to perform with complete commitment for the organisation and (3) desire to remain with the organisation (Agarwal, Decarlo \& Vyas, 1999; Allen \& Meyer, 1990; Chen, Tsui \& Farh, 2002; Uygur, 2004).

Meyer and Allen (1991) introduce the three dimensions of organisational commitment, namely (1) Affective commitment refers to the employee's emotional attachment and 
involvement with his or her organisation (Meyer, Allen \& Smith, 1993). (2) Continuance commitment is the employee's willingness to be a part of the organisation because of nontransferable investment (Reichers, 1985) and (3) Normative commitment relates to the employee's feelings of obligation to his or her work (Bolon, 1997).

Organisational commitment is beneficial from both the employee's and the organisation's point of view. Shore and Martin (1989) found that organisational commitment leads to the overall performance of the organisation and this also helps organisations achieve their targets. On the other hand, when discussing organisational commitment from the employee's perspective, Meyer, Paunonen, Gellatly, Goffin and Jakson (1989) found that greater organisational commitment increases the employee's in-rolejob performance which ultimately benefits the overall organisation. Thus, we hypothesised that:

- Hypothesis 2: There is positive and significant relationship between organisational commitment and in-role job performance.

In earlier studies, a weak relationship was found between job involvement and in-role job performance. Brown and Leigh (1996) argued that one reason for the weak and significant relationship between these two variables (i.e. job involvement and in-role job performance) may be that job involvement is more likely to influence in-role job performance in the presence of certain other variables (indirectly). Thus, keeping this argument in mind, this study is an attempt to find this relationship in the presence of organisational commitment because of the positive and significant relationship identified by the literature between job involvement and organisational commitment (Brown, 1996; Janis, 1989; Loui, 1995). This positive relationship indicates that all employees who are involved with their jobs are also committed to their organisations. Similarly, the researchers have found a positive relationship between organisational commitment and the performance of employees (Konovsky \& Cropanzano, 1991; Meyer et al., 1989). This finding revealed that employees who are more committed to their employing organisations make a great effort to achieve their organisation's goals by performing their tasks better. By considering the preceding argument as a whole, it was hypothesised that:

- Hypothesis 3: Organisational commitment mediates the relationship between job involvement and in-role job performance.

Previous studies have explored the relationship between dimensions of organisational commitment (affective, normative and continuance commitment) and job involvement, but no research to date has been conducted in which these dimensions have been used as a mediator between job involvement and in-role performance. As Allen and Meyer (1996) have noted, employees with higher ethical levels are not only more involved in their jobs, but also have strong normative commitment. Some other researchers also found a positive and significant relationship between normative commitment and job involvement (i.e. Ahmed \& Islam, 2011; Carmeli, 2005; Meyer \& Allen, 1997). In their separate studies, Zajac (1990), Carmeli (2005), Ahmed and Islam (2011), argued that there is a positive and significant relationship between affective commitment and job involvement. On the other hand, most researchers have discovered a weak but significant relationship between continuance commitment and job involvement (e.g. Ahmed \& Islam, 2011; Ketchand \& Strawser, 2001; Kuruu“zu“m, Ipekc, Etin \& Irmak, 2008; Zajac, 1990).

Similarly, researchers have also explored the relationship between dimensions of organisational commitment and inrole job performance. For example, Meyer et al. (1989) found a positive relationship between affective and normative commitment with in-role job performance. They also found that continuance commitment is negatively related with employee performance. Another researcher Caruana, Ewing and Ramaseshan (1997), explored the relationship between organisational commitment and performance and noted that affective commitment has a positive impact on performance, whilst normative and continuance commitment have no impact on performance. Likewise, Angle and Lawsan (1994) also found a positive relationship between affective and normative commitment and performance, whilst continuance commitment had no impact on performance. From the preceding discussion, it was hypothesised that:

- Hypothesis 4: Affective, continuance and normative commitment mediates the relationship between job involvement and in-role job performance.

\section{Research design}

In the present study a quantitative research design was employed using the questionnaire. A survey is 'a method for gathering information from a sample of individual's' (Scheuren, 2004, p. 9). The main idea of survey research is 'to collect information from one or more people on some set of organizationally relevant constructs' (Bartlett, 2005, p. 99). Moreover, the present study attempted to measure phenomena that was not directly observable which required a survey. This is considered to be an appropriate way to capture the findings from a large population at one time (Gall, Gall \& Brog, 2007).

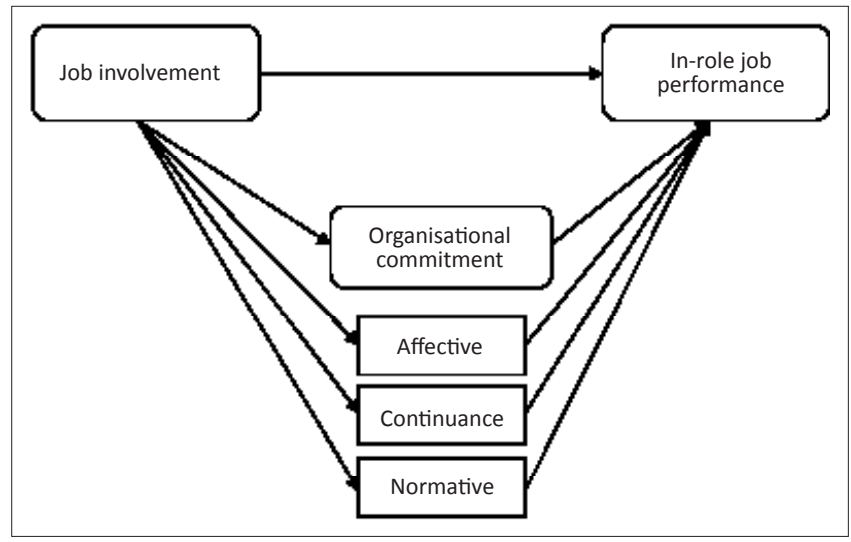

FIGURE 1: Research model showing mediating role of organisational commitment. 


\section{Research approach}

In this research the quantitative approach has been used. The main reason for choosing this method was that the variable used in this study can be easily measured quantitatively. On the other hand, according to Terre Blanche, Durrheim and Painter (2006), quantitative study is beneficial because the findings are more generalisable when using this approach.

\section{Research strategy}

Most of the studies on management use the survey method to collect the data. The same strategy has been used in the present study. This survey involved adapting questionnaires from the studies of different researchers. These questionnaires were distributed to the sample selected from the population (Ghauri \& Gronhaug, 2005).

\section{Research method}

\section{Research participants}

This study was conducted on the banking sector of Pakistan. There are approximately 207 banks registered with the web of the central bank of Pakistan. Out of these, 10 listed banks were selected on the basis of a simple random sampling technique. This technique was used because this gives equal chance to each member of the population to be chosen. Two-hundred and fifty questionnaires were distributed amongst the employees of selected banks, out of which 208 responded back, representing $83.2 \%$ of the total number of questionnaires.

\section{Measuring instruments}

Job involvement: Twenty three questions were used to measure the job involvement level of employees. These twenty-three questions were taken from the study of Knungo (1982) developed on the 5-point Likert scale varying from 5 (strongly agree) to 1 (strongly disagree). Examples of the questions used are:

- 'I like to spend most of my time at work.'

- 'Every morning I go to work enthusiastically.'

- 'When there are things to do, I leave home earlier to go to work.'

The reliability of these questions was found to be 0.88 .

Organisational commitment: Fifteen questions were used to measure the commitment level of the employees. These questions were developed by Mowday, Steers and Porter
(1979) on a 5-point Likert format whereby the highest point represented stronger commitment and vice versa (e.g. 5 - strongly agree, 4 - agree, 3 - neutral, 2 - disagree and 1 - strongly disagree). Furthermore, the same questions were used to measure the normative, continuance and affective commitment level of the employees. Examples of these questions are:

- 'I can comfortably tell people that the institution is a great place to work in.'

- 'I can see that my values are very similar to those of the institution.'

- 'It was certainly a mistake to have decided to work in this institution in the first place.'

The reliability of these questions was 0.92 .

In-role job performance: Five questions on in-role job performance were developed after extensive study of different books and of earlier researchers. These questions were developed on a 5-point Likert scale, varying from 5 (strongly agree) to 1 (strongly disagree). Examples are:

- 'I am doing well with my job.'

- 'I am completely aware of my work.'

- 'I can efficiently complete my tasks.'

The reliability of the questions was measured at 0.84 .

\section{Research procedure}

A direct method of distribution and collection of questionnaires was applied. Firstly, permission was obtained from the managers of the banks. Secondly, respondents were requested to be very fair and honest with their responses and they were assured that their responses would be kept confidential and used for research purposes only.

\section{Statistical analysis}

To analyse the data, Statistical Package for Social Sciences (SPSS version 17.0) was used. Pearson's correlation was used to determine the relationship between job involvement, organisational commitment (e.g. affective, normative and continuance) and in-role job performance. To measure the mediation effect of organisational commitment between job involvement and in-role performance Judd and Kenny's (1981) approach was used.

Descriptive statistics was also used to measure the mean and standard deviation of all the variables. Significance of the correlation was also found at a 0.05 level of significance.

TABLE 1: Mean, standard deviation, Cronbach and correlation.

\begin{tabular}{|c|c|c|c|c|c|c|c|c|}
\hline Variables & Mean & SD & 1 & 2 & 3 & 4 & 5 & 6 \\
\hline Job involvement & 2.906 & .363 & - & - & - & - & - & - \\
\hline Organisational commitment & 3.106 & .355 & $.594^{* *}$ & - & - & - & - & - \\
\hline In-role job performance & 3.639 & .457 & $.286^{* *}$ & $.289^{* *}$ & - & - & - & - \\
\hline Affective commitment & 3.136 & .474 & $.659^{* *}$ & $.847^{* *}$ & $.322^{* *}$ & - & - & - \\
\hline Normative commitment & 3.209 & .516 & $.255^{* *}$ & $.640^{* *}$ & $.214^{* *}$ & $.331^{* *}$ & - & - \\
\hline Continuance commitment & 2.951 & .512 & $.223^{* *}$ & $.589^{* *}$ & -.008 & $.252^{* *}$ & $.125^{* *}$ & - \\
\hline
\end{tabular}




\section{Results}

Table 1 shows the mean and standard deviation of the variables along with the correlation amongst the independent and dependent variables. The mean score of the respondents answer to the questions indicates that most of the respondents are very near to neutral in giving their views regarding job involvement $(M=2.906)$, commitment $(M=3.106)$, in-role job performance $(\mathrm{M}=3.639)$, affective commitment $(\mathrm{M}=3.136)$, normative commitment $(\mathrm{M}=3.209)$ and continuance commitment $(\mathrm{M}=2.951)$.

Figures in the table also indicate that correlation results of variables, namely, job involvement and in-role job performance were positively correlated with each other, but the relationship between them was not strong $(r=.286$, $p<.01)$. The literature also supports the weak relationship between job involvement and in-role job performance (e.g. Diefendorff et al., 2002; Mohsan et al., 2011). Job involvement and organisational commitment are positively related with each other $(r=.594, p<.01)$, but the relationship is moderately strong. Organisational commitment is also positively associated with in-role job performance $(r=.289$, $p<.01)$, but the relationship is found to be slightly weak. When all the dimensions of organisational commitment were compared with job involvement, they demonstrated positive and significant results. This was also the case with affective commitment $(r=.659, p<.01)$, normative commitment $(r=.255, p<.01)$ and continuance commitment $(r=.223, p<.01)$.

The results were also interpreted to determine the relationship between dimensions of commitment with inrole job performance. Two dimensions of commitment (i.e. affective and normative) positively correlated with performance, for example, affective commitment $(r=.322$, $p<.01)$ and normative commitment $(r=.214, p<.01)$, but there was a negative and insignificant relationship found between continuance commitment and in-role job performance (i.e. $r=-.008, p>.05)$. The literature also revealed a negative or no relationship between continuance organisational commitment and in-role job performance (Caruana et al., 1997).
To access the mediation effect of organisational commitment between job involvement and in-role job performance, three equations were examined according to the procedure given by Judd and Kenny (1981) (see Table 2). In the first equation, job involvement (independent variable) was regressed with organisational commitment (mediator). Here the relationship was found to be significant $(\beta=0.581, p<.01)$. In the second equation, the dependent variable (in-role job performance) was regressed with the independent variable (job involvement). Once again, the relationship was found to be significant $(\beta=0.361, p<.01)$. In the third and last equation both the independent variable (job involvement) and mediator (organisational commitment) were used as independent variables and regressed with the dependent variable (in-role job performance), and the relationship was again found to be significant $(\beta=0.233, p<.01)$. Thus, all Judd and Kenny's (1981) conditions for mediation were met, namely (1) there is significant relationship between independent and mediator variable, (2) there is significant relationship between independent and dependent variable, (3) there is significant relationship between mediating and dependent variables and (4) the effect of dependent variable is greater on mediating variable and the value of beta is greater in equation two then in equation three.

Judd and Kenny's (1981) method was once again used in Table 3 to access the mediation effect of affective commitment between job involvement and in-role job performance. In the first equation, job involvement (independent variable) was regressed with affective commitment (mediator) and the relationship was significant $(\beta=.859, p<.01)$. In the second equation, the independent variable (job involvement) was regressed with the dependent variable (inrole job performance) and the relationship was significant $(\beta=0.361, p<.01)$. In the third equation, both the independent variable (job involvement) and the mediator (affective commitment) were regressed with in-role job performance, and the relationship was significant. Moreover, the value of bets in equation two $(\beta=0.361)$ was greater compared to the value in equation three $(\beta=0.165)$. So, affective commitment is the mediator between job involvement and in-role job performance.

TABLE 2: Mediation effect for organisational commitment.

\begin{tabular}{|c|c|c|c|c|c|}
\hline Equation & Independent & Dependent & $r^{2}$ & $\beta$ & $F$-value \\
\hline 1 & Job involvement & Organisational commitment & 0.353 & 0.581 & 22.15 \\
\hline 2 & Job involvement & Performance & 0.082 & 0.361 & 18.36 \\
\hline \multirow[t]{2}{*}{3} & Job involvement & Performance & 0.101 & 0.233 & 11.48 \\
\hline & Organisational commitment & Performance & - & 0.221 & - \\
\hline
\end{tabular}

$r^{2}$, Coefficient of determination; $\beta$, Beta; $F$-value, Ronald A. Fisher test.

TABLE 3: Mediation test for affective commitment.

\begin{tabular}{|c|c|c|c|c|c|}
\hline Equation & Independent & Dependent & $r^{2}$ & $\beta$ & $F$-value \\
\hline 1 & Job involvement & Affective commitment & 0.434 & 0.859 & 17.85 \\
\hline 2 & Job involvement & Performance & 0.082 & 0.361 & 18.36 \\
\hline \multirow[t]{2}{*}{3} & Job involvement & Performance & 0.113 & 0.165 & 13.08 \\
\hline & Affective commitment & Performance & - & 0.227 & - \\
\hline
\end{tabular}

$r^{2}$, Coefficient of determination; $\beta$, Beta; $F$-value, Ronald A. Fisher test. 
Judd and Kenny's (1981) method was once again used in Table 4 to access the mediation effect of normative commitment between job involvement and in-role job performance In the first equation, job involvement (independent variable) was regressed with normative commitment (mediator), and the relationship was significant $(\beta=0.363, p<.01)$. In the second equation, the independent variable (job involvement) was regressed with the dependent variable (inrole job performance), and the relationship was significant ( $\beta=0.361, p<.01)$. In the third equation, both the independent variable (job involvement) and the mediator (normative commitment) were regressed with in-role job performance and the relationship was significant. Moreover, the value of bets in equation two $(\beta=0.361)$ was greater compared to the value in equation three $(\beta=0.312)$. Thus, affective commitment is the mediator between job involvement and in-role job performance.

Judd and Kenny's (1981) method was also used in Table 5 to access the mediation effect of continuance commitment between job involvement and in-role job performance. In the first equation, job involvement (independent variable) was regressed with continuance commitment (mediator), and the relationship was significant $(\beta=0.315, p<.01)$. In the second equation, the independent variable (job involvement) was regressed with the dependent variable (inrole job performance) and the relationship was significant ( $\beta=0.361, p<.01)$. In the third equation, both the independent variable (job involvement) and the mediator (normative commitment) were regressed with in-role job performance, and the relationship was insignificant. Moreover the value of bets in equation two $(\beta=0.361)$ were not greater compared to the value of beta in equation three $(\beta=0.382)$. Here, the last condition of Judd and Kenny (1981) was not met. Thus, it was inferred that continuance commitment does not mediate the relationship between job involvement and in-role job performance.

\section{Ethical considerations}

The Ethics in Research Committee of the Faculty of Management and Human Resource Development, Universiti Teknologi Manaysia, approved the evaluation.

\section{Potential benefits and hazards}

There were no benefits or hazards for participants who took part in the evaluation.

\section{Recruitment procedures}

Firstly, permission was obtained from the branch managers to conduct the questionnaires from their employees. When the permission was granted, all the employees were requested to participate in the research by filling in the questionnaires to the best of their knowledge and belief.

\section{Informed consent}

On the first page of the questionnaire the purpose, confidentiality of the data and the time that it would take to complete the questionnaire were described in detail.

\section{Data protection}

The primary evaluator was the only person who had access to the questionnaire. Both success and non-success cases were promised anonymity and were not identified by the evaluators.

\section{Trustworthiness \\ Reliability}

The questionnaire items are described in the Method section.

\section{Validity}

The evaluation focused on a specific programme and did not seek to generalise the findings to other similar programmes.

\section{Discussion}

This study is an attempt to find the relationship between job involvement and in-role job performance along with the mediation effect of overall organisational commitment and its dimensions. The results of the study indicate that job involvement is positively and significantly related with in-role job performance. However, a weak relationship was found between them which concurs with the results of earlier

TABLE 4: Mediation test for normative commitment.

\begin{tabular}{|c|c|c|c|c|c|}
\hline Equation & Independent & Dependent & $r^{2}$ & $\beta$ & $F$-value \\
\hline 1 & Job involvement & Normative commitment & 0.065 & 0.363 & 14.329 \\
\hline 2 & Job involvement & Performance & 0.082 & 0.361 & 18.365 \\
\hline \multirow[t]{2}{*}{3} & Job involvement & Performance & 0.103 & 0.312 & 11.789 \\
\hline & Normative commitment & Performance & - & 0.134 & - \\
\hline
\end{tabular}

$r^{2}$, Coefficient of determination; $\beta$, Beta; $F$-value, Ronald A. Fisher test.

TABLE 5: Mediation effect of continuance commitment.

\begin{tabular}{|c|c|c|c|c|c|}
\hline Equation & Independent & Dependent & $r^{2}$ & $\beta$ & $F$-value \\
\hline 1 & Job involvement & Continuance commitment & 0.050 & 0.315 & 10.823 \\
\hline 2 & Job involvement & Performance & 0.082 & 0.361 & 18.365 \\
\hline \multirow[t]{2}{*}{3} & Job involvement & Performance & 0.087 & 0.382 & 9.807 \\
\hline & Continuance commitment & Performance & - & -0.068 & - \\
\hline
\end{tabular}

$r^{2}$, Coefficient of determination; $\beta$, Beta; $F$-value, Ronald A. Fisher test. 
researchers (i.e. Brown \& Leigh, 1996; Diefendorff et al., 2002; Mohsan et al., 2011; Rotenberry \& Moberg, 2007). This significant relationship might indicate that people who are highly involved in their jobs perform better.

The results of the study also revealed that all the dimensions of organisational commitment were positively related with job involvement. However, the relationship between affective commitment and job involvement was found to be greater amongst all other dimensions of commitment. These results concur with the study of earlier researchers (i.e. Agarwal et al., 1999; Ahmed \& Islam, 2011; Carmeli, 2005; Chen et al., 2002; Meyer \& Allen, 1990, 1991, 1997; Uygur, 2004). These findings might reveal that employees who are more involved in their jobs feel a greater connection with their organisation and wish to continue with their present jobs because they enjoy their work.

Organisational commitment and its two dimensions are also found positively related with in-role job performance. These results concur with the results of previous researchers that found that affective and normative commitments had a positive impact on the performance of employees (Angle \& Lawsan, 1994; Caruana et al., 1997; Meyer et al., 1989), whilst the relationship between continuance commitment and the in-role performance of employees was found to be negative (Angle \& Lawson, 1994; Caruana et al., 1997). Looking at the relationship between the dimensions of commitment and job involvement, an interesting relationship can be seen between affective commitment and job involvement. This relationship indicates that all employees that are highly involved in their jobs have a greater connection with their organisation, whilst on the other hand the relationship between continuance commitment and involvement is relatively low, but significant.

The findings of the study also revealed that job involvement, not only directly but also indirectly (in the presence of organisational commitment), affects the in-role job performance of employees. To enhance the study, dimensions of organisational commitment were also observed to mediate the relationship and the results indicated that affective and normative commitment mediate the relationship between job involvement and in-role job performance. This means that all employees that are involved with their jobs and have an ethical and emotional attachment with their organisation might perform better as compared to those employees who are only involved with their jobs. On the other hand, continuance commitment is not a mediator between them. The reason may be that the literature and the results of the present study found no relationship between continuance commitment and in-role job performance.

\section{Practical implication}

The findings of the present study were very helpful for management as well as for organisations. The results state that job involvement is one of the vital weapons with which to increase the in-role job performance of the key employees of an organisation. In addition to this, previous researchers found that job involvement also affected other attitudinal and behavioural outcomes, for example, organisational commitment (Ahmed \& Islam, 2011; Brown, 1996) absenteeism (Harrison \& Martocchio, 1998) and turnover (Huselid \& Day, 1991). A low level of job involvement creates a less competitive position for the organisation relative to rival firms. Thus, fostering high levels of job involvement is one of the available tools managers can use to enhance the competitive position of their organisations. The crucial question is how managers can increase the level of job involvement amongst the employees of their organisation? Various researchers have explored this question and attempted to find answers to it. One option is to redesign the job by entrenching characteristics such, as autonomy, task identity, task significance and feedback. The job can also be made more interesting for the employee (Knoop, 1986; Rabinowitz \& Hall, 1977; Saal, 1978).

In the present study organisational commitment and its three dimensions show different results with job involvement and in-role job performance. Organisational commitment was found to be the mediator between job involvement and in-role job performance. This finding will reveal to managers that job involvement is not sufficient for eliciting performance from employees. Ethics and the emotional attachment of employees' to their organisation are also necessary. With regard to the dimensions of organisational commitment, a positive influence on performance was found between affective commitment and normative commitment (i.e. affective and normative commitment are mediating variables between job involvement and in-role performance), whilst continuance commitment is not a mediator between job involvement and in-role performance. One of the reasons for this might be that previous studies have found a negative and no relationship between continuance commitment and performance (Angle \& Lawsan, 1994; Caruana et al., 1997). In summing up, by increasing normative and affective commitment along with job involvement, the performance of employees can be enhanced to uplift the organisation.

\section{Limitation and future direction}

This study was an attempt to find the mediating effect of organisational commitment between job involvement and in-role job performance in the banking sector. There is a need to explore the same relationship in other sectors as well. In this study only one dependent variable (in-role job performance) was used. In future, other dependent variables such as job satisfaction and organisational citizenship behaviour (OCB) should be kept in mind. Researchers have explored the relationship between job involvement $\mathrm{OCB}$ and job satisfaction, but no one has conducted such types of study using commitment as a mediator. In the present study, questionnaires were conducted on employees only. The same questions should be conducted on supervisors of employees to determine their views on employees' performance. 


\section{Conclusion}

This study was conducted to find the mediation effect of organisational commitment along with its dimensions, namely, affective, normative and continuance commitment, on-job involvement and in-role job performance. This is the first issue discussed in this study and has not been discussed earlier by other researchers.

This study concluded that job involvement and in-role job performance are positively related with each other and that organisational commitment enhances their relationship through a mediation effect. When looking at the dimensions of organisational commitment, normative and affective commitment perform the role of a mediating variable between them. However, continuance commitment is not a mediating variable between them.

Affective and normative commitment were also found to have a positive correlation with job involvement and inrole job performance simultaneously, whilst a negative and insignificant relationship was found between continuance commitment and the in-role job performance of employees.

The present study is a contribution to the knowledge of the relationship between job involvement and the in-role performance of employees and that the indirect variable, organisational commitment increases the relationship between them.

\section{Acknowledgements Competing interests}

The authors declare that they have no financial or personal relationship(s) which may have inappropriately influenced them in writing this paper.

\section{Authors' contributions}

T.I. (Universiti Teknologi Malaysia) completed this evaluation as the requirement for the Ph.D degree in the field of management. I.A. (Universiti Teknologi Malaysia) helped in data collection procedure. S.U.R.K. (Universiti Teknologi Malaysia) and U.N.U.A. (Universiti Teknologi Malaysia) supervised the evaluation.

\section{References}

Agarwal, S., Decarlo, T.E., \& Vyas, S.B. (1999). Leadership behavior and organisational commitment: A comparative study of American and Indian salespersons. Journal of International Business Studies, 30(4), 724-741. http://dx.doi.org/10.1057/ palgrave.jibs.8490836

Ahmed, I., \& Islam, T. (2011). Decoding the relationship between employee's jobs related behaviors: A study of the telecom sector of Pakistan. International Journal of Business and Social Science, 2(8), 245-252.

Allen, N.J., \& Meyer, J.P. (1990). Organisational socialization tactics: A longitudinal analysis of links to newcomers' commitment and role orientation. Academy of Management Journal, 33, 847-858. http://dx.doi.org/10.2307/256294

Allen, N.J., \& Meyer, J.P. (1996). Affective, continuance, and normative commitment to the organisation: An examination of construct validity. Journal of Vocational Behavior, 49(3), 252-276. http://dx.doi.org/10.1006/jvbe.1996.0043

Angle, H.L., \& Lawson, M.B. (1994). Organisational commitment and employees performance ratings: Both type of commitment and performance count. Psychological Reports, 75, 39-51. http://dx.doi.org/10.2466/pr0.1994.75.3f.1539
Bartlett, K.R. (2005). Survey research in organisations. In R.A. Swanson \& E. Holton (Eds.), Research in organisations: Principles and methods of inquiry, (pp. 97-113). San Francisco: Berrett-Koehler.

Blau, G.J., \& Boal, K.B. (1987). Conceptualising how job involvement and organisational commitment affect turnover and absenteeism. The Academy of Management Review, 12, 288-300.

Bolon, D.S. (1997). Organisational citizenship behavior among hospital employees: A multidimensional analysis involving job satisfaction and organisational commitment. Hospital \& Health Services Administration, 42(2), 221-241. PMid:10167456

Borman, W.C., \& Motowidlo, S.J. (1997). Task performance and contextual performance: The meaning for personnel selection research. Human Performance, 10, 99-109. http://dx.doi.org/10.1207/s15327043hup1002_3

Brown, S.P. (1996). A meta-analysis and review of organisational research on job involvement. Psychological Bulletin, 120, 235-255. http://dx.doi org/10.1037/0033-2909.120.2.235

Brown, S.P., \& Leigh, T.W. (1996). A new look at psychological climate and its relationship to job involvement, effort and performance. Journal of Applied Psychology, 81, 358-368. http://dx.doi.org/10.1037/0021-9010.81.4.358, PMid:8751453

Carmeli, A. (2005). Exploring determinants of job involvement: An empirical test among senior executives. International Journal of Manpower, 26(5), 457-472. http://dx.doi.org/10.1108/01437720510615143

Caruana, A., Ewing, M., \& Ramaseshan, B. (1997). Organisational commitment and performance: The Australian public sector experience. School Research Series, performance: The Australian public sector expeting, Curtin University, Perth.

Chen, Z.X., Tsui, A.S., \& Farh, J.L. (2002). Loyalty to supervisor vs. organisational commitment: Relationships to employee performance in China. Journal of Occupational and Organisational Psychology $75,339-356$. http://dx do org/10.1348/096317902320369749

Cron, W.L. (1984). Industrial salesperson development: A career stages perspective. Journal of Marketing, 48, 41-52. http://dx.doi.org/10.2307/1251509

Diefendorff, J., Brown, D., Kamin, A., \& Lord, B. (2002). Examining the roles of job involvement and work centrality in predicting organisational citizenship behaviours and job performance. Journal of Organisational Behaviour, 23, 93108. http://dx.doi.org/10.1002/job.123

Dubinsky, A.J., \& Hartley, S.W. (1986). A path-analytic study of a model of salesperson performance. Journal of the Academy of Marketing Science, 4, 36-46. http:// dx.doi.org/10.1007/BF02722111

Feldman, A.S., \& Moore, W.E. (1982). Labor commitment and social change in developing areas. Connecticut: Grenwood Press Publishers.

Gall, M.D., Gall, J.P., \& Brog, W.R. (2007). Education research: An introduction. (8th edn.). Boston: Allyn and Bacon.

Gerpott, T.J. (1990). Intracompany job transfers: An exploratory two-sample study of the buffering effects of interpersonal support. Prevention in Human Services, 8, 113-137. http://dx.doi.org/10.1300/J293v08n01_09

Ghauri, P., \& Gronhaug, K. (2005). Research Methods in Business Studies. (3rd edn.). London: FT. Prentice Hall.

Hackett, R.D., Lapierre, L.M., \& Hausdorf, P.A. (2001). Understanding the links between work commitment constructs. Journal of Vocational Behavior, 58, 392413. http://dx.doi.org/10.1006/jvbe.2000.1776

Hackman, J.R., \& Lawler, E.E. (1971). Employee reactions to job characteristics. Journa of Applied Psychology, 55, 259-286. http://dx.doi.org/10.1037/h0031152

Harrison, D.A., \& Martocchio, J.J. (1998). Time for absenteeism: A 20-year review of origins, offshoots and outcomes. Journal of Management, 24, 305-350.

Huselid, M.A., \& Day, N.A. (1991). Organisational commitment, job involvement and turnover: A substantive and methodological analysis. Journal of Applied Psychology, 76, 380-391. http://dx.doi.org/10.1037/0021-9010.76.3.380

Janis, N.A. (1989). Organisational commitment, career factors and career/life stage. Journal of Organisational Behaviour, 10, 247-266. http://dx.doi.org/10.1002/ job.4030100305

Jaros, S.J. (1997). An assessment of Meyer and Allen's (1991) there-component mode of organizational commitment and turnover intention. Journal of Vocational Behavior, 51, 319-337.

Judd, C.M., \& Kenny, D.A. (1981). Process analysis: Estimating mediation in treatment evaluations. Evaluation Review, 5, 602-619.

Kanungo, R.N. (1982). Measurement of job and work involvement. Journal of Applied Psychology, 67, 341-349.

Ketchand, A.A., \& Strawser, J.R. (2001). Multiple dimensions of organisational commitment: Implications for future accounting research. Behavioral Research in Accounting, 13, 221-253. http://dx.doi.org/10.2308/bria.2001.13.1.221

Knoop, R. (1986). Job involvement: An elusive concept. Psychological Reports, 59, 451-456. http://dx.doi.org/10.2466/pr0.1986.59.2.451

Konovsky, M.A., \& Cropanzano, R. (1991). Perceived fairness of employee drug testing as a predictor of employee attitudes and job performance. Journal of Applied Psychology, 76, 698-707. http://dx.doi.org/10.1037/0021-9010.76.5.698, PMid:1960142

Kuruu"zu"m, A., Ipekc, I.C., Etin, E., \& Irmak, S. (2008). Path analysis of organisational commitment, job involvement and job satisfaction in Turkish hospitality industry. Tourism review, 64(1), 4-16

Lee, J., \& Peccei, R. (2007). Perceived organizational support and affective commitment: The mediating role of organization-based self-esteem in the context of job insecurity. Journal of Organizational Behavior, 28(6), 661-685. 
Lodahl, T., \& Kejner, M. (1965). The definition and measurement of job involvement. Journal of Applied Psychology, 49, 24-33. http://dx.doi.org/10.1037/h0021692, PMid:14279757

Loui, K. (1995). Understanding employee commitment in the public organisation A study of the juvenile detention center. International Journal of Public Administration, 18, 1269-1295. http://dx.doi.org/10.1080/01900699508525052

Mathieu, J.E., \& Farr, J.L. (1991). Further evidence for the discriminant validity of measures of organisational commitment, job involvment, and job satisfaction. Journal of Applied Psychology, 76, 127-133. http://dx.doi.org/10.1037/0021 9010.76.1.127

Mathieu, J.E., \& Zajac, D.M. (1990). A review and meta-analysis of the antecedents, correlates, and consequences of organisational commitment. Psychological Bulletin, 108(2), 171-194. http://dx.doi.org/10.1037/0033-2909.108.2.171

Mayhew, M.G., Ashkanasy, N.M., \& Dan Gardner, J. (2007). A study of the antecedents and consequences of Psychological Ownership in organizational settings. Journal of Social Psychology, 147(5), 477-500.

Meyer, J.P., \& Allen, N.J. (1990). The measurement and antecedents of affective, continuance and normative commitment. Journal of Occupational Psychology, $63,1-18$.

Meyer, J., \& Allen, N. (1991). A three-component conceptualization of organizational commitment. Human Resource Management Review, 1, 61-89.

Meyer, J.P., \& Herscovitch, L. (2001). Commitment in the workplace: Toward a general model. Human Resource Management Review, 11(3), 299-326.

Meyer, J.P., Allen, N.J., \& Smith, C.A. (1993). Commitment to organisations and occupations: Extension and test of a three-component conceptualization. Journal of Applied Psychology, 78(4), 538-552. http://dx.doi.org/10.1037/0021 9010.78.4.538

Meyer, J.P., Allen, N.J., \& Smith, C.A. (1993). Commitment to Organizations and Occupations: Extension and Test of a Three-Component Conceptualization. Journal of Applied Psychology, 78(4), 538-551.

Meyer, J.P., \& Allen, N.J. (1997). Commitment in the Workplace. Thousand Oaks, CA: Sage.

Meyer, J.P., Paunonen, S.V., Gellatly, I.R., Goffin, R.D., \& Jakson, D.N. (1989) Organisational commitment and job performance: It's the nature of commitment that counts. Journal of Applied Psychology, 74, 152-156. http://dx.doi. org/10.1037/0021-9010.74.1.152

Mohsan, F., Nawaz, M.M., Khan, M.S., Shaukat, Z., Islam, T., Aslam, N. et al. (2011) Impact of job involvement on organisational citizenship behavior (OCB) and inrole job performance: A Study on banking sector of Pakistan. European Journal of role job performance: A Study on
Social Sciences, 24(4), 494-502.

Mowday, R., Steers, R., \& Porter, L. (1979). The measurement of organisational commitment. Journal of Vocational Behavior, 14, 224-247. http://dx.doi. org/10.1016/0001-8791(79)90072-1
Paterson, J.M., \& O'Driscoll, M.P. (1990). An empirical assessment of Kanungo's (1982) concept and measure of job involvement. Applied Psychology - An Internationa concept and measure of job involvement. Applied Psychology - An International
Review, 39, 293-306. http://dx.doi.org/10.1111/j.1464-0597.1990.tb01055.x

Paullay, I., Alliger, G., \& Stone-Romero, E. (1994). Construct validation of two instruments designed to measure job involvement and work centrality. Journal of
Applied Psychology, 79, 224-228. http://dx.doi.org/10.1037/0021-9010.79.2.224

Porter, L.W., Steers, R.M., Mowday, R.T., \& Boulian, P.V. (1974). Organizational commitment, job satisfaction and turnover among psychiatric technicians. Journal of Applied Psychology, 59(5), 603-609.

Rabinowitz, S., \& Hall, D.T. (1977). Organisational research on job involvement. Psychological Bulletin, 84, 265-288. http://dx.doi.org/10.1037/00332909.84.2.265

Reichers, A. (1985). A review and reconceptialitzion of organisational commitment. The Academy of Management Review, 10(3), 465-476. PMid:10300307

Rotenberry, P.F., \& Moberg, P.J. (2007). Assessing the impact of job involvement on performance. Management Research News, 30, 203-215. http://dx.doi. org/10.1108/01409170710733278

Saal, F.E. (1978). Job involvement: A multivariate approach. Journal of Applied Psychology, 63, 53-61. http://dx.doi.org/10.1037/0021-9010.63.1.53

Scheuren, F. (2004). What is a survey? Alexandria, VA: American Statistical Associaton.

Sekaran, U. (1989). Paths to the job satisfaction of banking employees. Journal of Organisational Behaviour, 10, 347-359. http://dx.doi.org/10.1002/ job.4030100405

Sekeran, U., \& Mowday, R.T. (1981). A cross cultural analysis of the influence of individual and job characteristics on job involvement. International Review of Applied Psychology, 30, 51-64. http://dx.doi.org/10.1111/j.1464-0597.1981. tb00979.x

Shore, L.M., \& Martin, H.J. (1989). Job satisfaction and organisational commitment in relation to work performance and turnover intentions. Human Relations, 42(7), 625-638. http://dx.doi.org/10.1177/001872678904200705

Shore, L.M., Newton, L.A., \& Thornton, G.C. (1990). Job and organisational attitudes in relation to employee behavioral intentions. Journal of Occupational Behavior, 11 57-67. http://dx.doi.org/10.1002/job.4030110108

Terre Blanche, M., Durrheim, K., \& Painter, D. (2006). Research in practice: Applied methods for the social sciences. Cape Town: University of Cape Town Press.

Uygur, A. (2004). Örgütselbaglılıkveisgörenperformansı.TürkiyeVakıflarBankası Ankara, stanbulve zmirilisubelerineyönelikalanarastırması.YayımlanmamısDoktoraTezi. Hacettepe Üniversitesi, SosyalBilimlerEnstitüsü.

Zajac, E.J. (1990). CEO selection, succession, compensation and firm performance: A theoretical integration and empirical analysis. Strategic Management Journal, 11, 217-230. 